\title{
STUDIES IN OSTEOPETROSIS
}

\author{
BY \\ C. E. DENT, JEAN M. SMELliE, and L. WATSON \\ From the Metabolic Ward and Paediatric Department, University College Hospital, London
}

(RECEIVED FOR PUBLICATION JUNE 3, 1964)

Much attention has been paid to the rare, but spectacular bone disease known as osteopetrosis, Albers-Schönberg disease, or marble bones disease. It was first defined as a clinical entity in 1904 by Albers-Schönberg and the name osteopetrosis was introduced by Karshner in 1926. Many cases have since been reported and at intervals good review articles have appeared including those of McCune and Bradley (1934), Higinbotham and Alexander (1941), Pines and Lederer (1947), Seigman and Kilby (1950), Kneal and Sante (1951), and Hasenhuttl (1962). It is clear that the severe form presenting at birth is quite different clinically and genetically from the milder form which presents usually in adolescence or later (Turano, Fagan, and Corbo, 1954; Enell and Pehrson, 1958; Lièvre, Milhaud, and Camus, 1962). The severe congenital form is characterized by a remarkable homogeneity of greatly abnormal physical and radiological findings. All affected children show the same radiological findings in their bones and the same severe secondary haematological changes, consequent on the great reduction and in some cases almost complete obliteration of bone marrow. Most of the bone abnormalities can be immediately related to a quantitative, and perhaps also a qualitative, deficiency of osteoclasts as seen histologically (Kneal and Sante, 1951; Piatt, Erhard, and Araj, 1956; Engfeldt, Fajers, Lodin, and Pehrson, 1960). This is also shown by the persistence of too much calcified cartilage formed in the early chain of events of endochondral bone formation, and by a failure of remodelling of the bone during growth. As a result little or no bone marrow space is formed and the metaphyses show a characteristic club shape. Furthermore, the bone foramina, such as those through which the cranial nerves pass, fail to enlarge during growth, leading to a slow destruction of the nerves in question, yet another serious consequence of the osteoclastic deficiency.

Osteopetrosis of the severe form is inherited as if determined by an autosomal recessive gene (Enell and Pehrson, 1958). This fact, together with the clinical data, suggests very strongly that the disease is the result of an inborn error of metabolism. From this aspect, however, the literature makes depressing reading. No consistent biochemical abnormalities have yet been discovered that could have suggested a dysfunction of a single simple enzymic process. Plasma levels of calcium, phosphorus, and phosphatase are usually normal or inconsistently abnormal. No disorder closely linked to parathyroid or vitamin D dysfunction has been uncovered. Clearly, however, a hypofunctioning parathyroid gland could be invoked as a theoretical cause of the deficient osteoclastic activity. Likewise an oversensitivity to vitamin $D$ may be present, for the radiographic appearances in osteopetrosis may resemble those in the severe form of 'idiopathic hypercalcaemia of infancy' (Fanconi, Girardet, Schlesinger, Butler, and Black, 1952), a disease in which such a mechanism may be involved.

A characteristic but puzzling feature of the untreated disease is that the bone radiographs of older survivors show signs of fluctuating activity of the osteosclerotic process. Commonly the clubshaped metaphyses show transverse alternating bands of greater and less density (Fairbank, 1948). Close examination shows that the less dense segments may show early signs of remodelling. According to our basic theory, such apparent fluctuations in true disease activity, in the face of a presumed constant genetic biochemical abnormality, indicate that the environment is also very much concerned in the disease pathogenesis (Dent, 1957), and suggest plausible forms of treatment. In this study we began from the premise that the modifying environmental factor was probably dietary and linked to calcium intake. Our tentative hypothesis was that the primary biochemical abnormality was an overabsorption of calcium from the diet resulting from an unidentified disordered mechanism. If this were so, profound changes in the development of the disease process should follow régimes aimed to produce 

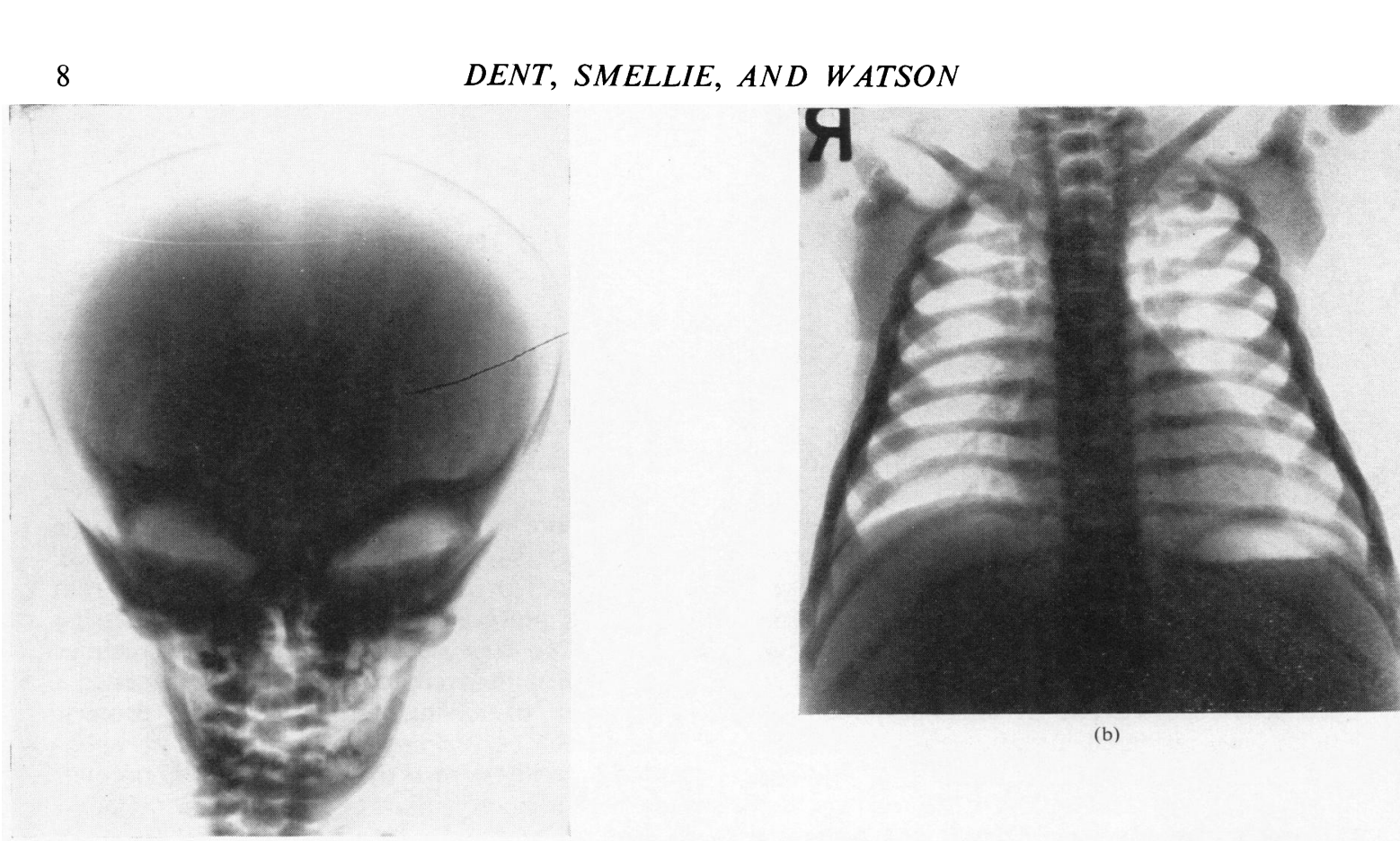

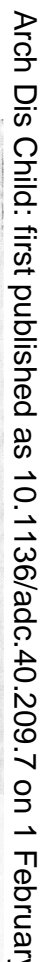

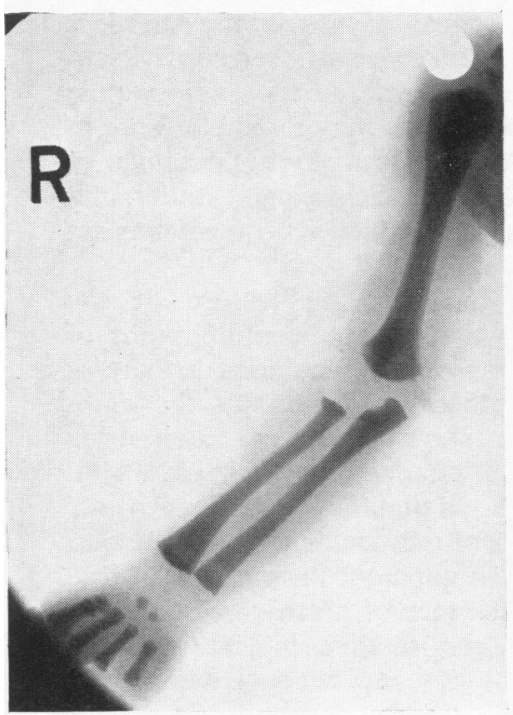

(c)

Fig. 1.-Bone radiographs when Kenneth was less than 1 year. (a) Skull at $4 \frac{1}{2}$ months; (b) chest at 4 months; (c) right arm at $4 \frac{1}{2}$ months; (d) latera view of spine at $4 \frac{1}{2}$ months; (e) femur at 5 months.
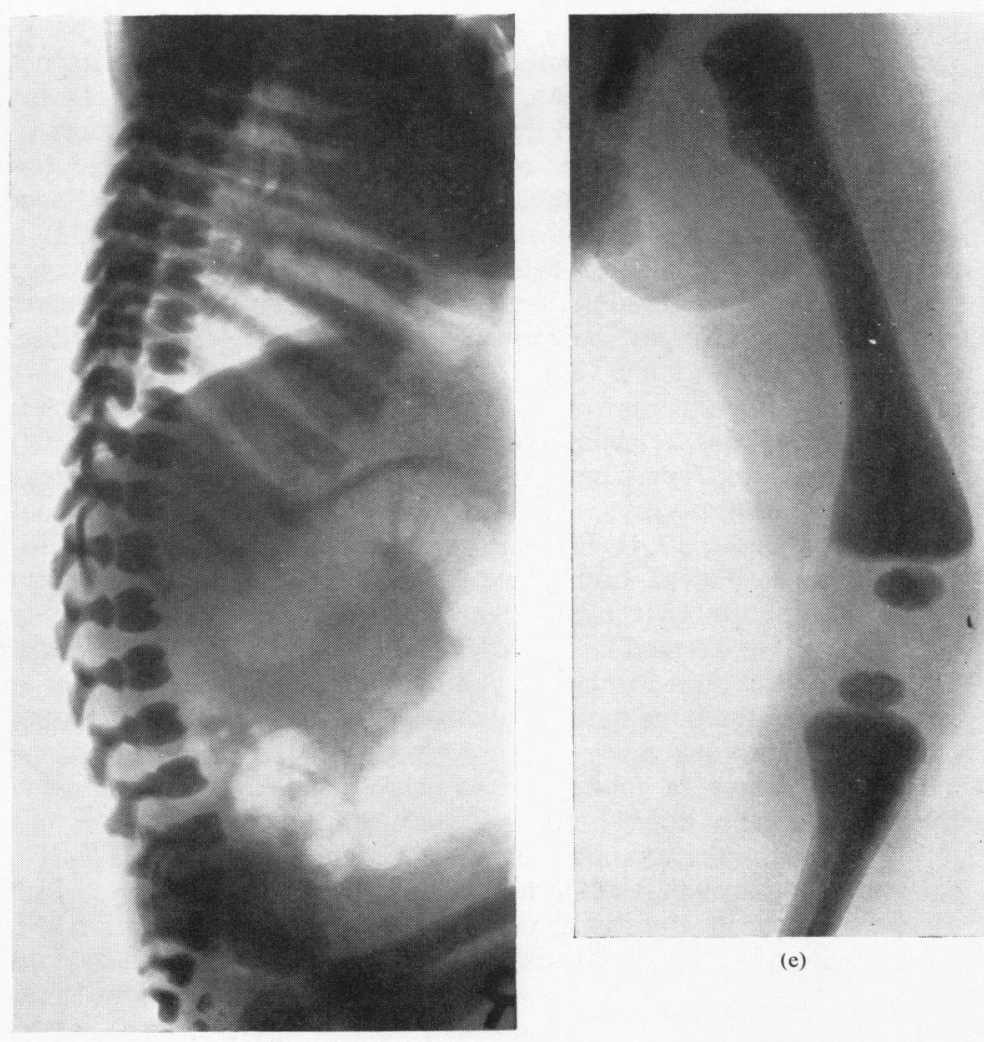

ริ

(b)

(d)

(e)

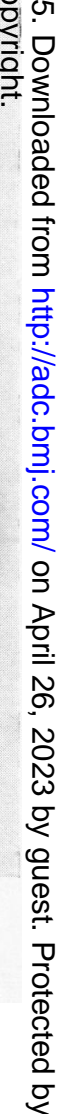


calcium depletion. We are reporting here the effect in a child with osteopetrosis of treatment suggested by this basic hypothesis.

\section{Case Report}

History on Admission. Kenneth M., the second child of normal parents, was born at term on September 1, 1957, with the assistance of forceps for a contracted pelvis. His birth weight was $7 \mathrm{lb}$. $6 \mathrm{oz}$. (3.4 kg.) and the only abnormality noted on initial examination was two erupted teeth which were extracted at 5 days.

$\mathrm{He}$ was noticeably pale from the age of 3 weeks and after confirmation of some degree of anaemia, treatment with oral iron and intramuscular vitamin $B_{12}$ was instituted with improvement. He also became snuffly, had frequent upper respiratory tract infections with cough, continuous rhinorrhoea, and consequent feeding difficulty. His mother noticed increasing prominence of his eyes and also of his scalp veins. He was fed on a standard evaporated milk schedule and solids were introduced from 2 months. Supplements of vitamins were added from 1 month in an approximate daily dosage of vitamin C, 25 mg. and vitamin D, 850 i.u.

At the age of 3 months, a radiological diagnosis of Albers-Schönberg disease was made at the U.S.A.F. Base Hospital, Ruislip, and he was transferred to the care of Dr. Bernard Schlesinger and one of us (C.E.D.) at University College Hospital on December 19, 1957.

The parents, aged 31 and 29 years, were unrelated, they and the patient's elder brother aged 21 years were normal. There was no family history of bone disease.

Clinical Examination on Admission. He was a pale baby (aged $3 \frac{1}{2}$ months) weighing $10 \mathrm{lb} .6 \mathrm{oz} .(4 \cdot 7 \mathrm{~kg}$.) (3rd percentile), adequately nourished, with a relatively large head, short limbs, and a prominent abdomen. Length $24 \frac{1}{2}$ in. $\left(61 \cdot 5 \mathrm{~cm}\right.$.), upper segment $15 \frac{1}{2}$ in. $(39 \mathrm{~cm}$.), lower segment 9 in. $(22.5 \mathrm{~cm}$.), span 23 in. $(57 \cdot 5 \mathrm{~cm}$.), head circumference $16 \frac{1}{2}$ in. $(41 \cdot 5 \mathrm{~cm}$.).

He was snuffly, with a profuse mucopurulent nasal discharge. The bridge of the nose was depressed, accentuating the prominent eyes and there was frontal and parietal bossing. The anterior fontanelle was visibly full, pulsating, and measured about $5 \mathrm{~cm}$. in diameter. The fontanelle tension was approximately $40 \mathrm{~cm}$. water by tocodynamometer (Dr. C. N. Smyth). He was mouthbreathing with noisy respirations due to his pharyngeal secretions. The heart sounds were normal. The lower ribs were splayed by the distended abdomen in which the liver and spleen were palpable $4-5 \mathrm{~cm}$. below the costal margin. There was no generalized lymphadenopathy. He appeared to hear, and he made sounds. The pupils reacted to light; the optic discs were grey without papilloedema, and the fundi were otherwise normal. $\mathrm{He}$ followed a slowly moving light with eye movements. The limb movements and his responses, the reflexes, and muscle tone appeared normal for his age.

Preliminary Investigations. Haemoglobin $57 \%(8 \cdot 2 \mathrm{~g} . /$ $100 \mathrm{ml}$.). The blood smear showed numerous nucleated red cells, total white cell count $29,000 /$ c.mm., the differential count showing neutrophils $52 \%$, lymphocytes $35 \%$, eosinophils $1 \%$, immature cells $4 \%$, and myelocytes $8 \%$, platelets $89,000 / \mathrm{c} . \mathrm{mm}$. Routine examination of urine normal. Bone radiographs showed increased density with lack of cortico-medullary differentiation. The metaphyses were clubbed and showed longitudinal striations (Fig. 1a-e). Clear CSF of normal composition, under a pressure of $190 \mathrm{~mm}$., was obtained by lumbar puncture. Plasma calcium varied from $8 \cdot 5-9 \cdot 5 \mathrm{mg}$. $/$ $100 \mathrm{ml}$. with normal fractions (protein-bound calcium $2 \cdot 7$, complexed calcium $0 \cdot 5$, and ionized calcium $5 \cdot 7 \mathrm{mg}$. $/ 100 \mathrm{ml}$.)(Dr. G. A. Rose). Plasma inorganic phosphorus 2.3-3.1 mg./100 ml., plasma alkaline phosphatase $25 \cdot 8$ $31.5 \mathrm{~K}$.A. units, blood urea $21 \mathrm{mg} . / 100 \mathrm{ml}$. Serum proteins: total $8.1 \mathrm{~g} . / 100 \mathrm{ml}$., albumin $5.3 \mathrm{~g} . / 100 \mathrm{ml}$., globulin $2.8 \mathrm{~g}$. $/ 100 \mathrm{ml}$. Serum was normal on electrophoresis. Urinary chromatography showed no abnormality of amino acid excretion. The urinary Sulkowitch reaction was low on repeated examinations and the 24-hour urinary calcium was $5 \mathrm{mg}$.

Many of the investigations and treatments carried out during a period of study lasting 5 years are summarized in Fig. 2. Fig. 3 shows his appearance at $2 \frac{1}{2}$ years. Fig. $4 a$ and $b$ shows the radiological appearances in the knees and wrists at the age of 5 years and a diagrammatic interpretation of the changes, correlated with dates, is shown in Fig. 5. Calcium balances are tabulated in the Table. For convenience, the further investigations, treatment, and progress will be considered in two parts, (A) the early studies performed before March 1960 and (B) the later ones after that date.

\section{(A) Investigations, Treatment, and Progress}

Ammonium Chloride. Starting on January 16, 1958, a short trial of ammonium chloride in a daily dose of 0.5 $1.0 \mathrm{~g}$. was given in an attempt to increase urinary calcium excretion. The urinary $p \mathrm{H}$ fell from 6.7 to $5 \cdot 5$ without affecting the plasma bicarbonate of $21 \mathrm{mEq} / \mathrm{l}$. The $24-$ hour calcium excretions were $15 \mathrm{mg}$. and $26 \mathrm{mg}$. on two occasions. The trial of ammonium chloride had to be abandoned on February 16, 1958, because of persistent anorexia and vomiting.

Diet. From January 16, 1958, at the age of $4 \frac{1}{2}$ months, a low calcium diet (approximately $200 \mathrm{mg}$. daily) was introduced in the form of Locasol (Trufood), and vitamin $\mathrm{D}$ additions were discontinued. After eight months on this intake his mother thought he was eating very little and attributed this to the Locasol which she exchanged for cows' milk, the daily calcium intake being increased to approximately $300 \mathrm{mg}$. After four months of this, Locasol was again substituted on our recommendation (Fig. 2).

Transfusions. Between the ages of 4 and 7 months, five transfusions of packed red cells were required (Fig. 2). The recurrent anaemia was undoubtedly being aggravated by withdrawal of blood for biochemical examination. After the age of 7 months the haemoglobin level was maintained between 80 and $100 \%(11 \cdot 8-14 \cdot 8 \mathrm{~g} . / 100 \mathrm{ml}$.), no further transfusions being required. The white cell 


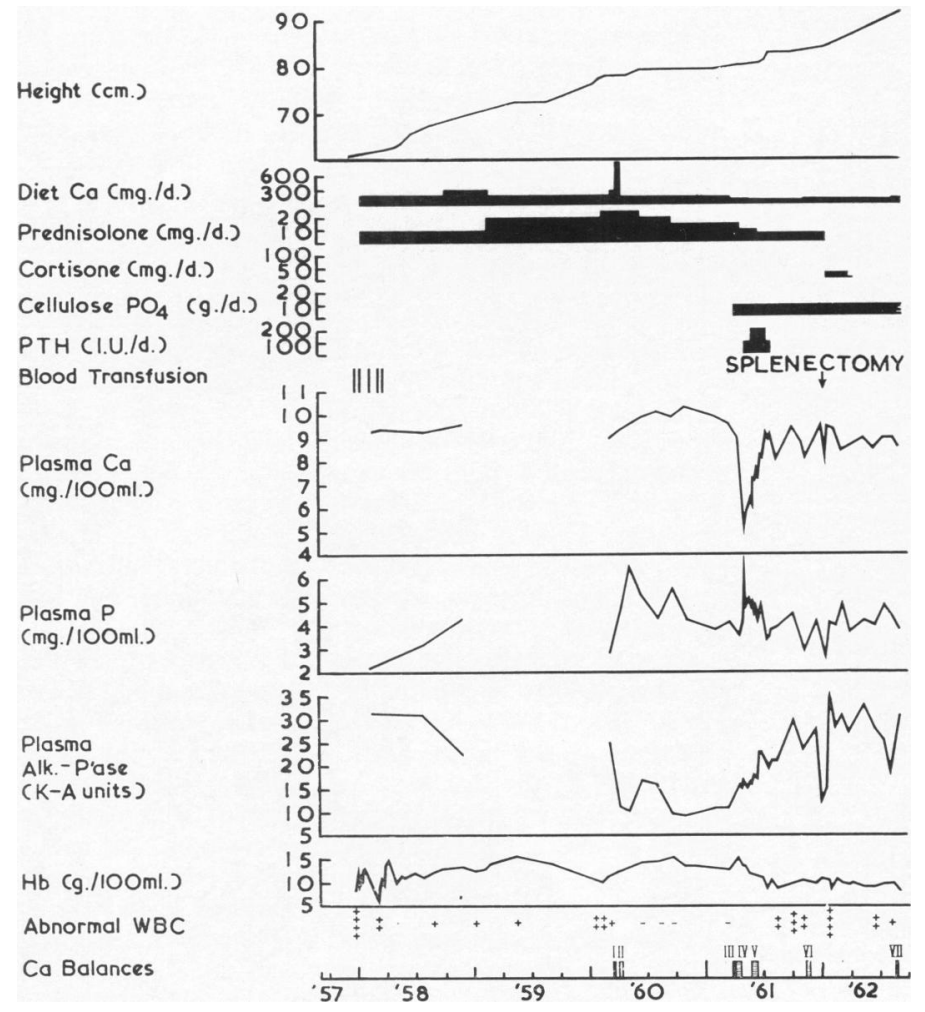

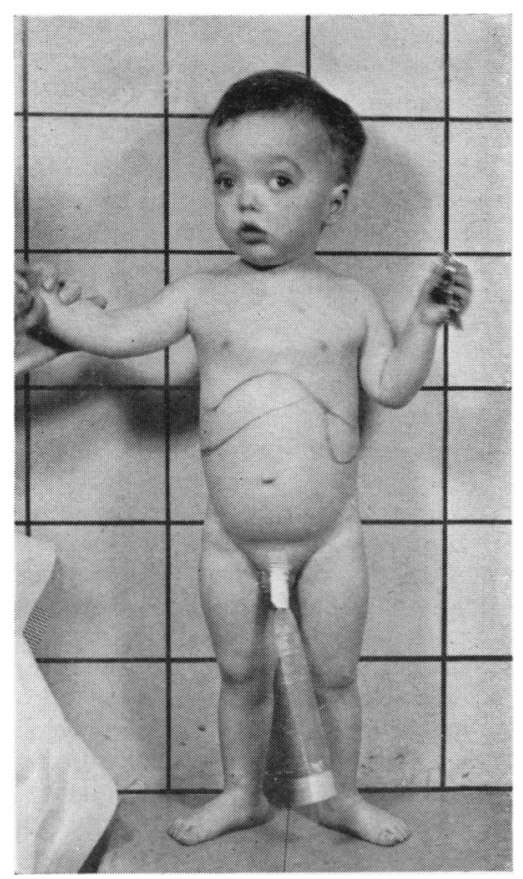

FIG. 3.-Kenneth $M$. at $2 \frac{1}{2}$ years. The outlines of the liver and spleen are marked.

FIG. 2.-Clinical and biochemical data on Kenneth M. during the whole course of his study.

count fell, circulating immature white cells virtually disappeared, and the platelet count returned to normal (Fig. 2).
Corticosteroids. On February 16, 1958, at the age of $5 \frac{1}{2}$ months prednisolone $10 \mathrm{mg}$. daily was started in the hope of prolonging the intervals between transfusions and

TABLE 1

CALCIUM BALANCES (IN SIX-DAY PERIODS) DURING VARIOUS THERAPY TRIALS

\begin{tabular}{|c|c|c|c|c|c|c|}
\hline $\begin{array}{l}\text { Trial } \\
\text { No. }\end{array}$ & Date & $\begin{array}{l}\text { Daily } \\
\text { Calcium } \\
\text { Intake } \\
\text { (mg.) }\end{array}$ & $\begin{array}{l}\text { Daily } \\
\text { Faecal } \\
\text { Calcium } \\
\text { (mg.) }\end{array}$ & $\begin{array}{c}\text { Daily } \\
\text { Urine } \\
\text { Calcium } \\
\text { (mg.) }\end{array}$ & $\begin{array}{l}\text { Calcium } \\
\text { Balance } \\
(\mathrm{mg} / \text { day })\end{array}$ & Other Treatments \\
\hline 1 & $\begin{array}{l}\text { 11-16 March, } 1960 \\
17-22 \text { March, } 1960\end{array}$ & $\begin{array}{l}282 \\
282\end{array}$ & $\begin{array}{l}75 \\
75\end{array}$ & $\begin{array}{l}113 \\
105\end{array}$ & $\begin{array}{r}+94 \\
+102\end{array}$ & Prednisolone $25 \mathrm{mg}$. daily \\
\hline 2 & $\begin{array}{l}\text { 1-6 April, } 1960 \\
\text { 7-12 April, } 1960\end{array}$ & $\begin{array}{l}890 \\
890\end{array}$ & $\begin{array}{l}259 \\
238\end{array}$ & $\begin{array}{l}55 \\
45\end{array}$ & $\begin{array}{l}+576 \\
+607\end{array}$ & Prednisolone $25 \mathrm{mg}$. daily \\
\hline 3 & $\begin{array}{c}\text { 22-27 March, } 1961 \\
28 \text { March-2 April, } 1961\end{array}$ & $\begin{array}{l}97 \\
97\end{array}$ & $\begin{array}{l}10 \\
10\end{array}$ & $\begin{array}{l}15 \\
12\end{array}$ & $\begin{array}{l}+72 \\
+75\end{array}$ & Prednisolone $15 \mathrm{mg}$. daily \\
\hline 4 & $\begin{array}{l}\text { 3-8 April, } 1961 \\
\text { 9-14 April, } 1961 \\
\text { 15-20 April, } 1961\end{array}$ & $\begin{array}{l}97 \\
97 \\
97\end{array}$ & $\begin{array}{l}90 \\
99 \\
91\end{array}$ & $\begin{array}{l}4 \\
3 \\
2\end{array}$ & $\begin{array}{l}+3 \\
-5 \\
+4\end{array}$ & $\begin{array}{l}\text { Prednisolone } 15 \mathrm{mg} \text {. daily } \\
\text { Cellulose phosphate } 10 \mathrm{~g} \text {. daily }\end{array}$ \\
\hline 5 & $\begin{array}{l}\text { 18-23 May, } 1961 \\
\text { 24-29 May, } 1961 \\
\text { 30 May-4 June, } 1961 \\
\text { 5-10 June, } 1961\end{array}$ & $\begin{array}{l}80 \\
80 \\
80 \\
80\end{array}$ & $\begin{array}{l}63 \\
\\
54 \\
48 \\
47\end{array}$ & $\begin{array}{l}2 \\
2 \\
3 \\
2\end{array}$ & $\begin{array}{l}+15 \\
+24 \\
+29 \\
+31\end{array}$ & 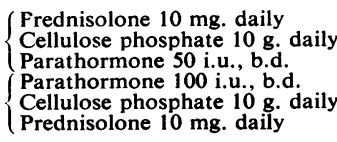 \\
\hline 6 & $\begin{array}{l}\text { 11-16 Nov., } 1961 \\
\text { 17-22 Nov., } 1961\end{array}$ & $\begin{array}{l}84 \\
84\end{array}$ & $\begin{array}{l}86 \\
78\end{array}$ & $\begin{array}{l}3 \\
3\end{array}$ & $\begin{array}{l}-5 \\
+3\end{array}$ & $\begin{array}{l}\text { Prednisolone } 7.5 \mathrm{mg} \text {. daily } \\
\text { Cellulose phosphate } 10 \mathrm{~g} \text {. daily }\end{array}$ \\
\hline 7 & $\begin{array}{l}\text { 18-23 Aug., } 1962 \\
\text { 24-29 Aug., } 1962\end{array}$ & $\begin{array}{l}120 \\
120\end{array}$ & $\begin{array}{l}81 \\
90\end{array}$ & $\begin{array}{r}6 \\
11\end{array}$ & $\begin{array}{l}+33 \\
+\quad 19\end{array}$ & Cellulose phosphate $10 \mathrm{~g}$. daily \\
\hline
\end{tabular}




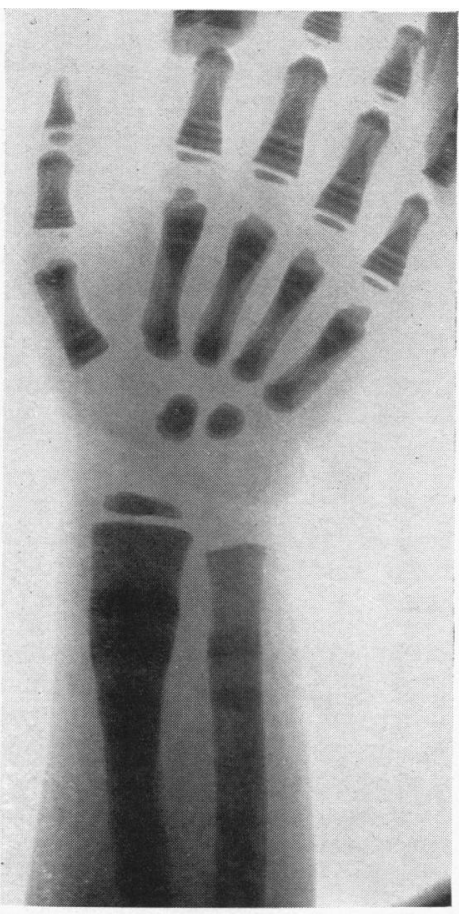

(a)

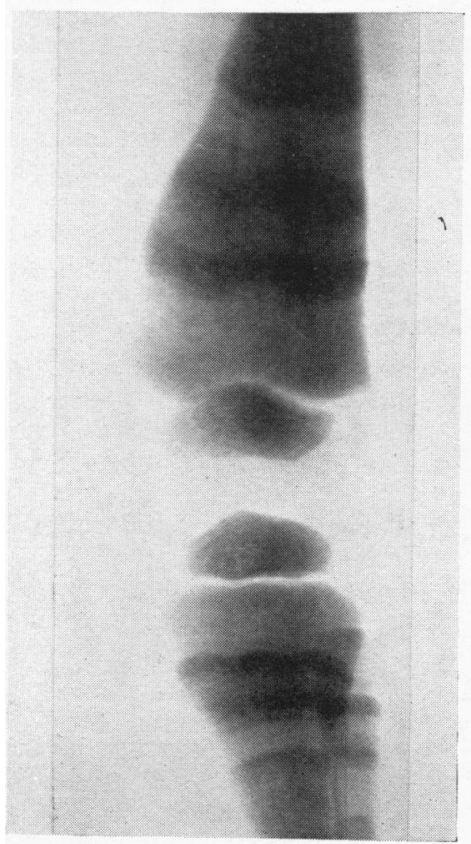

(b)

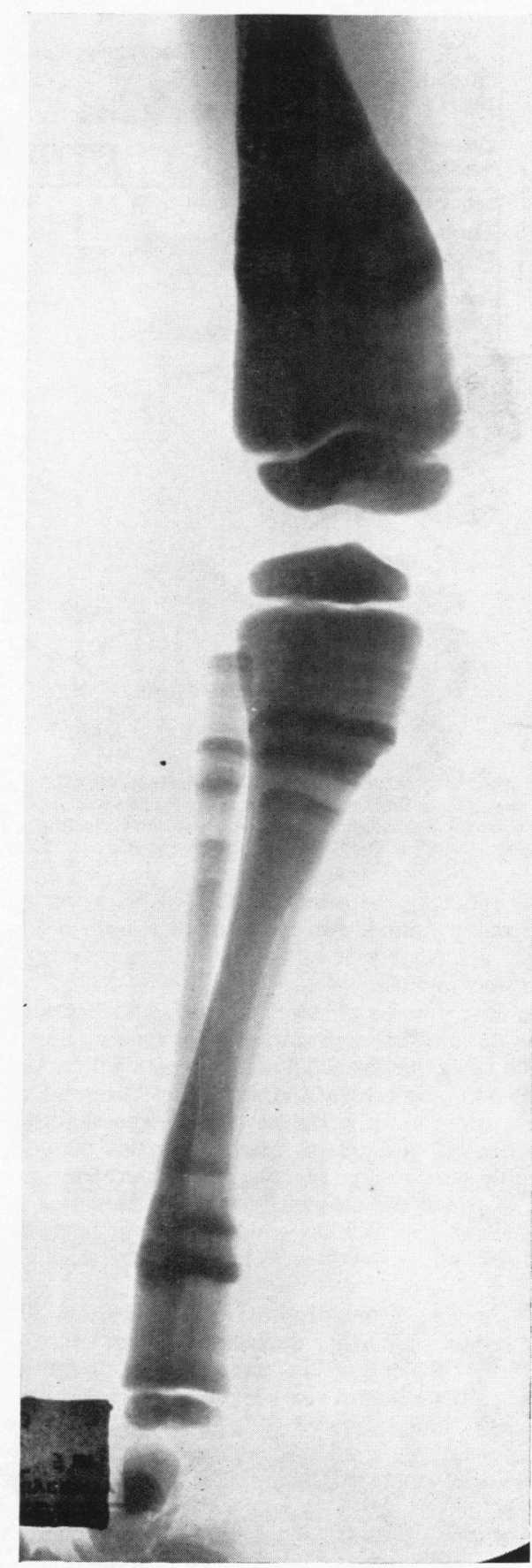

(c)

Fig. 4.-Bone radiographs when Kenneth was 5 years and over. (a) Right wrist at 5 years; (b) left knee at 5 years: the tracing shown on Fig. 5 is from a radiograph of one month later; (c) right leg at 5 years and 10 months. 


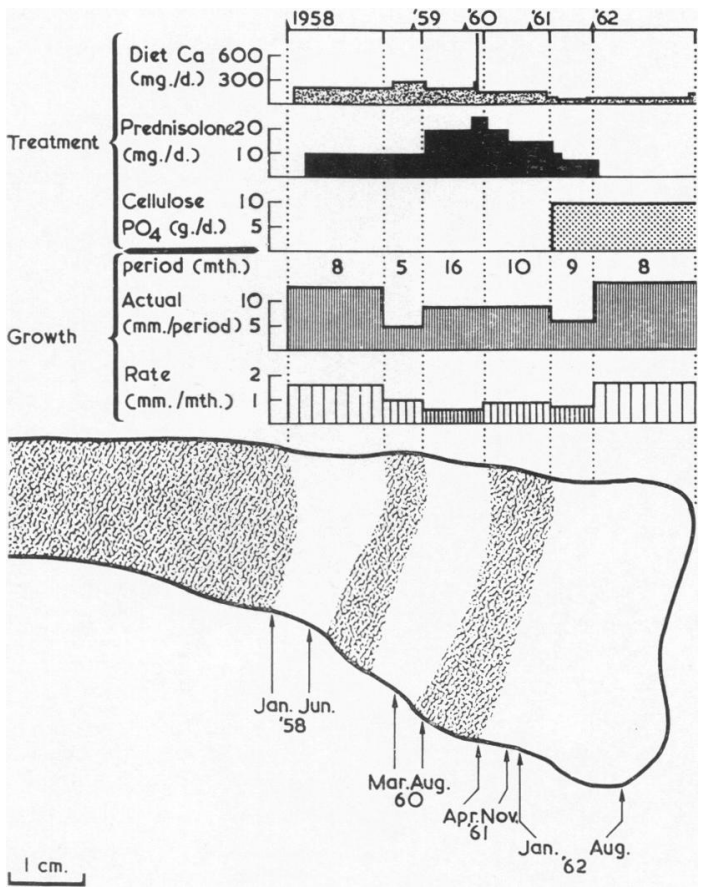

FIG. 5.-Tracing of left femur of Kenneth M. (Sept. 19, 1962). The datings shown have been derived from radiographs taken during his study. Changes in treatment and growth rate corresponding to this period of growth are shown above.

possibly reducing the mineralization of his bone. This dosage was continued for one year, increased to $20 \mathrm{mg}$. daily for a further year and then to $25 \mathrm{mg}$. daily for a further four months.

After four months of steroid therapy and low calcium diet the radiological appearances were encouraging (Fig. 5). The new bone formed was translucent with a suggestion of modelling both at the wrists and knees. During the next three months the new bone was slightly less translucent but the growth rate during this period was reasonably satisfactory (Fig. 5). In the next four-month period in which the calcium intake was increased from approximately 200 to $300 \mathrm{mg}$. daily the bone formed was very dense and growth rate appeared to slow down (Fig. 5).

After the dose of prednisolone was increased to $20 \mathrm{mg}$. daily there was a further deposition of less dense bone (Fig. 5). At the end of his second year of prednisolone therapy, at the age of 2 years and 5 months, his haemoglobin level had fallen to $64 \%(9.6 \mathrm{~g} . / 100 \mathrm{ml}$.) with reappearance of circulating immature cells and the prednisolone dosage was then increased to $25 \mathrm{mg}$. daily.

Mile-stones. Kenneth's general development was retarded though early and prolonged hospital admission and impaired vision may have contributed to this. He raised his head in the supine position at 6-7 months, sat at 1 year, stood and walked with support from 16 months and alone from 22 months. This was conducted on a wide base and with his legs externally rotated at the hips. He made noises from an early age and said 'Dad' from 1 year. He spoke three to four words with meaning from 18 months and proceeded to chatter continuously in a rather toneless voice.

The first dentition began to erupt at 10 months and continued irregularly. He continuously mouth-breathed because of the nasal discharge and poor airway and he dribbled saliva copiously. His eyes became less prominent but he developed a marked divergent strabismus by the age of 16 months. He could still appreciate light and darkness, apparently, reaching for toys and objects of support. At 19 months examination under anaesthesia confirmed bilateral optic atrophy. By 2 years 4 months he had a roving nystagmus and by 3 years there was no pupillary light reflex. Examination under anaesthesia then showed very atrophic discs but normal vasculature. He still succeeded in walking about in familiar surroundings remarkably well.

\section{(B) Investigations, Treatment, and Progress}

On reviewing Kenneth's first $2 \frac{1}{2}$ years it was remarkable how much bone growth had varied both in rate and density (Fig. 5). It seemed that the first period of improvement in growth and bone density occurred when he was given a strict low calcium diet and a small dose of prednisolone and that radiological bone density increased and modelling failed to occur during the time when the mother allowed a little more calcium in the food. Increased prednisolone dosage produced improvement radiologically but an unsatisfactory rate of growth. It was clear that careful balance studies were now needed in addition to the other data to help assess these responses.

The investigations undertaken during this period included 6-day calcium and phosphorus balances at varying intervals and on different dietary calcium intakes with regular plasma calcium, phosphorus, and alkaline phosphatase estimations (Fig. 2) and fluoroscopy of the lower ends of radius and femur every few months (Fig. 5). Dietary intake of calcium and steroid dosage were adjusted in accordance with these data.

Haematological Investigations and Treatment. During 1960 and 1961 Kenneth's growth was most unsatisfactory (Figs. 2 and 5). It appeared that this was due in part to the prednisolone and the dosage was progressively lowered. After April 1961 there was a return of the anaemia and later of abnormal white cells in the peripheral blood (Fig. 2).

Radioisotope studies were then undertaken by $D r$. T. A. J. Prankerd and Dr. A. J. Bowdler, who reported as follows.

'(1) November 1961. ${ }^{51} \mathrm{Cr}$ studies showed a marked reduction in the red cell life-span to approximately 4 days. The principal site of red cell destruction as indicated by surface counting was the spleen. ${ }^{59} \mathrm{Fe}$ studies showed rapid uptake and release by the spleen, maximal activity being found 24 hours after injection of the plasma-bound isotope. Surface counting over the lumbar spine and liver showed evidence of slight erythropoiesis; the spleen was, however, the most active site in this respect. The 
over-all erythropoietic rate appeared to be in excess of the normal requirement.

(2) April 1962. (3 months after splenectomy.) ${ }^{51} \mathrm{Cr}$ studies showed red cell survival at the lower limits of the normal range (T-half $\mathrm{Cr} 24$ days). ${ }^{59} \mathrm{Fe}$ studies showed the liver to be the most active site of erythropoiesis. Anaemia at this time was due to impaired red cell production and not to haemolysis.

(3) August $1962 .{ }^{59} \mathrm{Fe}$ study showed the liver to be the most active site of erythropoiesis. No very active erythropoiesis was detectable in the lumbar spine or thigh.'

In view of the results of the isotope studies performed in November 1961 splenectomy was carried out on January 11,1962 by Mr. G. L. Bunton. The spleen with splenunculus weighed $205 \mathrm{~g}$. and histologically it showed active erythropoietic centres. Post-operatively cortisone was substituted for prednisolone and steroids were discontinued altogether in April 1962. The haemoglobin level settled between $9 \cdot 2$ and $9 \cdot 9 \mathrm{~g} . / 100 \mathrm{ml}$. and circulating immature cells persisted.

There was a striking increase in growth rate and improvement in the radiological appearances when the steroids were stopped (Figs. 2 and 5).

Diet and Calcium Balances (Fig. 2 and Table). On a normal ( $890 \mathrm{mg}$. daily) calcium intake he was in strongly positive calcium balance (trial No. 2). On a low calcium intake (282 and $97 \mathrm{mg}$. daily) he remained in positive calcium balance (trials No. 1 and 3). It was only when cellulose phosphate (Balston Ltd.), $10 \mathrm{~g}$. daily, was added to the very low calcium diet, $97 \mathrm{mg}$. daily, that approximate calcium. balance was achieved (trial No. 4). Trial No. 6 showed that this effect was still maintained seven months later and trial No. 7 showed that with the greatly improved growth that followed splenectomy and withdrawal of steroid therapy he was still only in slightly positive balance with a slightly increased calcium intake (120 mg. daily).

In all these studies we had some difficulty in obtaining complete urine collections. This did not appreciably affect the calcium balance since urine calcium was always very low. Phosphorus balances reflected this uncertainty and are not, therefore, quoted here.

Parathyroid Hormone. Cellulose phosphate $10 \mathrm{~g}$. daily was added to his other treatment in April 1961. So effective was this treatment in preventing gastro-intestinal absorption of calcium that one month after its start (in May 1961) Kenneth was admitted with severe hypocalcaemic tetany. The plasma calcium was $4.8 \mathrm{mg}$. $/ 100$ ml., phosphorus $7.0 \mathrm{mg} . / 100 \mathrm{ml}$. and alkaline phosphatase 10 K.A. units (Fig. 2).

The only change then introduced into his therapeutic régime was the addition of parathyroid hormone (Eli Lilly) by injection 50 units twice daily, increased after two weeks to 100 units twice daily. A small dose of vitamin D (about 900 i.u. daily) was also started.

There was rapid clinical improvement. The plasma calcium rose and returned to normal by mid-July when the parathyroid hormone was reduced and then stopped. There was no recurrence of tetany.
Tetracycline. Maintenance tetracycline was given throughout the five years to help control his recurrent upper respiratory tract infections.

Radiology. New bone formation was followed carefully in serial radiographs and the composite final picture is shown diagrammatically in Fig. 5. By correlating the dates on the corresponding graph it can be seen that the alternating bands of dense and translucent bone can be related to treatment. Dense bands correspond to periods of slightly increased calcium intake or of slow growth. The most recent bone growth is of normal density and shows some modelling. This took place during the 8-month period of vigorous dietary calcium depletion and withdrawal of prednisolone. No dense bands appeared during this period, but there was no apparent decrease in density of the bone already formed elsewhere and no evidence of medullary cavity formation. In some intermediate radiographs it was noted that the subperiosteal bone laid down in the shafts of long bones was also striated, in rough correspondence with the metaphysial changes.

Growth and General Progress. Rate of growth in height as measured clinically (Fig. 2), or radiologically (Fig. 5) was steadily decreasing from the age of 2 years. Almost no growth occurred while he was having $25 \mathrm{mg}$. prednisolone daily and very little in the following 19 months when he was having small doses. Following splenectomy and the withdrawal of steroid therapy he had a sudden and continuous growth spurt. He left our care in September 1962 to return home to the U.S.A. and then measured $36 \cdot 5$ in. $(91 \cdot 2 \mathrm{~cm}$.). We are indebted for a later follow-up to Dr. Amos Christie (Vanderbilt University) who reported that in July 1963 his height was $39 \cdot 5$ in. $(100 \mathrm{~cm}$.), so that it is clear that the good progress shown during the last six months of our study has been maintained. A radiograph taken at this time is shown in Fig. 4c.

Kenneth's general condition remained satisfactory throughout. There was no deterioration in his haematological signs, and in spite of his divergent strabismus and bilateral optic atrophy he was able to walk around in familiar surroundings and was climbing and becoming more adventurous. He was able to hear, and joined in conversation with short sentences. Air studies of his ventricles were not undertaken though it was considered likely that he was hydrocephalic (head circumference 22.75 in. $(57.7 \mathrm{~cm}$.) at 5 years). At the age of 5 there was some mental and physical retardation, but special nursery schooling was already being considered for him at the time of his return home to the U.S.A.

\section{Discussion}

For reasons mentioned in our introduction we have attempted to modify bone growth in this child by depleting him of bone mineral. We chose calcium depletion rather than phosphate, as calcium deficiency symptoms seemed more likely to be limited to the skeleton, and as calcium balances used to measure the eificiency of treatment are much easier to interpret than phosphorus balances. One of us (C.E.D.) had 
indeed attempted phosphate deprivation some years ago on another similar child. Aluminium hydroxide was given to bind the dietary phosphate, but the results were inconclusive probably because the phosphate absorption mechanism is so much more efficient than that for calcium (unpublished data).

Our early follow-up was difficult to interpret and largely unsuccessful because we did not realize that the child could utilize the calcium so efficiently even on low calcium diets. We were also giving fair doses of prednisolone, mainly to control the anaemia, but also hoping that perhaps this too would lessen gut absorption of calcium. When we discovered that the child was in positive balance on $100 \mathrm{mg}$. a day of calcium it was clear that even more severe calcium depletive measures needed to be taken. We, therefore, added the cellulose phosphate, then being currently used in this Department and by our colleagues at the Royal National Orthopaedic Hospital on adults with idiopathic hypercalcuria (Parfitt, Higgins, Nassim, Collins, and Hilb, 1964). This did make the calcium balance zero (Table), but this was still of no avail since bone growth at that time had practically ceased probably owing to the prednisolone. We were forced, therefore, to consider the haematological aspects more seriously. Our studies, giving similar results to those described by Sjölin (1959), suggested that splenectomy would be advisable since the spleen was destroying red cells faster than it was making them. Following splenectomy, we were able to withdraw the prednisolone slowly and bone growth became rapid soon after. The ensuing rapid deposition of less dense bone showing clear signs of remodelling can only be attributed to our therapy and it was furthermore encouraging to note how much better the child became clinically. Clearly a longer follow-up is necessary for fuller assessment of this therapy, but this is now out of our hands as the family has returned to their home in the U.S.A. We think, nevertheless, that the results of this study are sufficiently striking to recommend that it should be repeated on some further affected children and as soon as possible after diagnosis. Fortunately, this is usually in the first months of life owing to the conspicuous nature of the various disease manifestations. If prevention of some of the neurological complications could be achieved it would provide more striking evidence of effectiveness. A further study is also needed to try and distinguish the separate effects of the splenectomy and low calcium régime.

We wonder now how far this study may have contributed to our understanding of the disease pathogenesis. Clearly if a full clinical cure of the disease were to follow such a calcium-depleting régime begun soon after birth, this would strongly favour intestinal overabsorption of calcium as the only disorder. Such a cure would have to include the formation of normal bone marrow with normal peripheral blood, as well as the formation of normally structured bones and prevention of the blindness and other distressing neurological complications. Unfortunately, one known fact suggests already that this is an over-simplification, namely, the fact that the disease is already partly manifest at birth, indeed has been diagnosed radiologically in utero (Jenkinson, Pfisterer, Latteier, and Martin, 1943). This fact suggests either that the placenta shares the gut defect and in some way transfers too much calcium from the mother to the foetus, or, perhaps more likely, that the bones themselves (or rather the primary cartilage) have an increased ability to take up calcium from circulating body fluids thus manifesting a further basic biochemical defect. It is when the theoretical interpretation thus begins to be increasingly complicated, that our present concept of an inborn error of metabolism becomes helpful. This tells us that there must be a simple biochemical cause operating from the simple primary genetic defect, the multiplicity of clinical and other features being secondary to this. A moderately low calcium intake does not lead to a more than temporary negative calcium balance in most people since it is soon followed by compensating improvements in calcium absorption and decreased losses in the urine (Malm, 1958). Similarly under conditions of rapid bone growth, such as those during childhood, improved calcium absorption occurs. The underlying mechanism of these adaptations is ill understood but many have speculated on the possible blood-borne factor that would appear to be operating in these circumstances, normally correlating so very accurately the functions of gut, bones, and kidney. A gross overactivity of such a single factor could explain in our child the combination of excessive calcium deposition in metaphysial cartilage at the same time as the gut is overabsorbing dietary calcium, the two being as usual so accurately coordinated as to occur without change in plasma levels. The very low urine calcium in the presence of normal plasma levels could also be due to this action.

We are especially interested here to recall the temporary severe state of hypoparathyroidism which this child went through when first put on the full calcium-depleting régime. We have not yet put a normal child on this régime, but much experimental work suggests that a normal child would not manifest tetany owing to the very efficient parathyroid mechanism for maintaining plasma calcium levels. Adults certainly do not. We are not aware of 
tetany from a calcium-depleting régime being previously reported as a feature of marble bones disease. It suggests some previous mild parathyroid suppression, but the mechanism of this appears obscure since the child constantly showed substantially normal total, and on the one occasion tested, ionized plasma calcium levels. It has been postulated that the parathyroid glands produce at least two hormones, one regulating plasma calcium and phosphorus levels, the other directly controlling osteoclastic activity (Dent, 1962). If this is true it may be that our child when on a more normal calcium intake showed a parathyroid suppression, mainly concerning the osteoclast stimulating hormone. This theory fits well the known abnormalities in the bone histology and radiographs and suggests an explanation for the improvement we found in $x$-ray density and remodelling after some time on the severely calcium-poor régime (Fig. 5), during which parathyroid function was presumed to have become normal.

Clearly a long follow-up and trial of further cases is necessary for final appraisal of the possible benefits of this treatment, for it is theoretically inadequate in that it can claim to correct only one aspect of the disease process, namely, the overabsorption of calcium by the gut. It is vitally important to discover whether the other features of the disease may be modified should it be possible to apply the same treatment soon after birth.

\section{Summary}

A child with the severe congenital form of osteopetrosis (Albers-Schönberg disease) has been studied from 3 months to 5 years of age.

The anaemia was controlled by adequate corticosteroid treatment but only at dosages that slowed or inhibited growth in stature.

Attempts were made to deplete the child of calcium by dietary means. Only partial control of bone density, as seen on radiographs, could at first be achieved. Calcium balances confirmed the suspected gross overpositivity. Excessive calcium absorption seems to be an important feature of th? disease.

More severe calcium restriction did not produce negative balance. Addition of cellulose phosphate to the very low calcium diet made the balance zero, the child first going through a state of severe hypocalcaemic tetany as if parathyroid function had been previously suppressed. It may be that some of the disease manifestations can be explained on the basis of diminished action of parathyroid hormone on the bones.

Red cell studies showed that most of the active marrow was in the liver and spleen and most of the red cell destruction in the spleen. After splenectomy the red cell life-span markedly increased and it was possible to reduce and soon abandon corticosteroid therapy.

During the last months of the child's follow-up he continued on the strict calcium-depleting régime without corticosteroid therapy. He showed a large spurt in growth, became more lively and active, and laid down less dense bone, which showed signs of remodelling.

The parents, both U.S. citizens on temporary stay in Britain, have asked us to record their gratitude to the National Health Service which bore the entire cost of this study in the ordinary course of its working. We thank the biochemists in the Metabolic Ward and Pathology Laboratories for performing the appropriate investigations.

\section{REFERENCES}

Albers-Schönberg, H. (1904). Röntgenbilder einer seltenen Knochenerkrankung. Münch. med. Wschr., 51, 365.

Dent, C. E. (1957). Foreword to Symposium on inborn errors of metabolism. Amer. J. Med., 22, 671 .

(1962). Some problems of hyperparathyroidism. Brit. med.J., 2, 1419 and 1495 .

Enell, H., and Pehrson, M. (1958). Studies on osteopetrosis. I. Clinical report of three cases with genetic considerations. Acta paediat. (Uppsala), 47, 279.

Engfeldt, B., Fajers, C. M., Lodin, H., and Pehrson, M. (1960). Studies on osteopet rosis. III. Roentgenological and pathologicanatomical investigations on some of the bone changes. ibid., 49, 391.

Fairbank, H. A. T. (1948). Osteopetrosis: osteopetrosis generalisata, marble bones, Albers-Schönberg's disease, osteosclerosis fragilitas generalisata. J. Bone Jt Surg., 30-B, 339.

Fanconi, G., Girardet, P., Schlesinger, B., Butler, N., and Black, J. (1952). Chronische Hypercalcämie, kombiniert mit Osteosklerose, Hyperazotämie, Minderwuchs und kongenitalen Missbildungen. Helv. paediat. Acta, 7, 314.

Hasenhuttl, K. (1962). Osteopetrosis: review of the literature and comparative studies on a case with a twenty-four-year follow-up. J. Bone Jt Surg., 44A, 359.

Higinbotham, N. L., and Alexander, S. F. (1941). Osteopetrosis: four cases in one family. Amer. J. Surg., 53, 444.

Jenkinson, E. L., Pfisterer, W. H., Latteier, K. K., and Martin, M. (1943). A prenatal diagnosis of osteopetrosis. Amer. J. Roentgenol., 49, 455.

Karshner, R. G. (1926). Osteopetrosis. ibid., 16, 405.

Kneal, E., and Sante, L. R. (1951). Osteopetrosis (marble-bones): report of a case with special reference to early roentgenologic and pathological findings. Amer. J. Dis. Child., 81, 693.

Lièvre, J-A., Milhaud, G., and Camus, J-P. (1962). Ostéopétrose. F́tude d'une famille comportant 12 sujets touchés en 4 générations: étude métabolique à l'aide du calcium radio-actif. Rev. Rhum., $29,258$.

McCune, D. J., and Bradley, C. (1934). Osteopetrosis (marble bones) in an infant : review of the literature and report of a case. Amer. J. Dis. Child., 48, 949.

Malm, O. J. (1958). Calcium requirement and adaptation in adult man. Scand. J. clin. Lab. Invest., 10, Suppl. 36.

Parfitt, A. M., Higgins, B. A., Nassim, J. R., Collins, J. A., and Hilb, A. (1964). Metabolic studies in patients with hypercalciuria. Clin. Science. In the press.

Piatt, A. D., Erhard, G. A., and Araj, J. S. (1956). Benign osteopetrosis: report of nine cases. Amer. J. Roentgenol., 76, 1119.

Pines, B., and Lederer, M. (1947). Osteopetrosis: Albers-Schönberg disease (marble bones). Report of a case and morphologic study. Amer. J. Path., 23, 755.

Seigman, E. L., and Kilby, W. L. (1950). Osteopetrosis : report of a case and review of recent literature. Amer.J. Roentgenol., 63, 865.

Sjölin, S. (1959), Studies on osteopetrosis. II. Investigations concerning the nature of the anaemia. Acta paediat. (Uppsala), 48, 529.

Turano, A. F., Fagan, K. A., and Corbo, P. A. (1954). Variations in clinical manifestations of osteopetrosis: report of two cases. J. Pediat., 44, 688. 